\title{
Preparing teachers in the professional development system for participation in textbook development in the USA
}

\section{Preparando professores no sistema de desenvolvimento profissional para participação no desenvolvimento de livros didáticos nos EUA}

\section{Preparar a los maestros en el sistema de desarrollo profesional para participar en el desarrollo de libros de texto en los Estados Unidos}

\author{
Olga Myhaylivna Elbrekht ${ }^{1}$ iD, Ivan Bakhov² ${ }^{\text {iD }}$, Kateryna Vukolova ${ }^{3}$ iD \\ Larysa Davydivna Kostenko4 iD
}

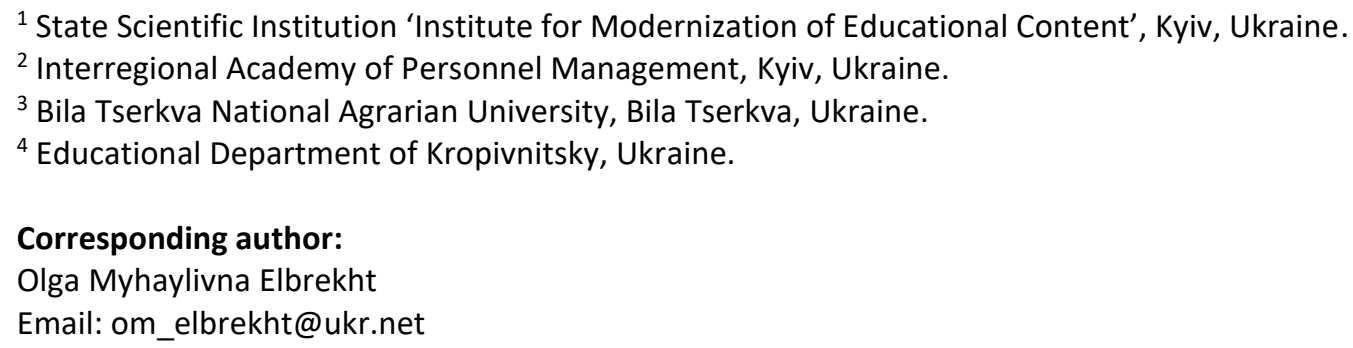

How to cite: Elbrekht, O. M., Bakhov, I., Vukolova, K., \& Kostenko, L. D. (2021). Preparing teachers in the professional development system for participation in textbook development in the USA. Revista Tempos e Espaços em Educação, 14(33), e169111. http://dx.doi.org/10.20952/revtee.v14i33.16911

\begin{abstract}
The article is devoted to the problem of preparing teachers for participation in the development of textbooks in the system of professional development in the USA. The authors analyze scientific works, which discuss the role of teachers in this activity, highlight the challenges teachers face in it and substantiate the importance of their appropriate training. The analysis revealed the peculiarities of the organization, forms and methods of teacher training, which adapt the USA system of professional development to preparing teachers for participation in textbooks development.

Keywords: Textbook development. Teacher involvement. Professional development. Peculiarities.

\section{RESUMO}

O artigo se dedica ao problema da preparação de professores para a participação no desenvolvimento de livros didáticos no sistema de desenvolvimento profissional dos Estados Unidos. Os autores analisam trabalhos científicos, que discutem o papel do professor nesta atividade, destacam os desafios que os professores enfrentam e fundamentam a importância da sua formação adequada. A análise revelou as peculiaridades da organização, formas e métodos de
\end{abstract}


formação de professores, que adaptam o sistema de desenvolvimento profissional dos EUA para preparar professores para participação no desenvolvimento de livros didáticos.

Palavras-chave: Desenvolvimento de livro didático. Envolvimento do professor. Desenvolvimento profissional. Peculiaridades.

\section{RESUMEN}

El artículo está dedicado al problema de preparar a los docentes para la participación en la elaboración de libros de texto en el sistema de desarrollo profesional de los EE. UU. Los autores analizan trabajos científicos, que discuten el papel del docente en esta actividad, destacan los desafíos que enfrentan los docentes en la misma y corroboran la importancia de su adecuada formación. El análisis reveló las peculiaridades de la organización, formas y métodos de formación docente, que adaptan el sistema de desarrollo profesional de EE. UU. Para preparar a los docentes para la participación en el desarrollo de libros de texto.

Palabras clave: Desarrollo de libros de texto. Participación del maestro. Desarrollo profesional. Peculiaridades.

\section{INTRODUCTION}

Relevance of research. The purpose of education, and hence effective development of educational programs and textbooks as the main means of its implementation, should be meeting the needs, requirements, expectations of society and the population served by a particular educational institution. In the conditions of rapid transformational changes in society, these documents of the educational process are constantly considered, revised, changed in the context of education reform. The requirements for textbooks are constantly reviewed and changed accordingly. An important condition for their successful correction or development is the involvement of stakeholders, especially teachers - people who are directly involved in student training. Despite the fruitfulness of such pedagogical activity, the approach to it is not clearly defined, as evidenced by research results. The article discusses the role of teachers in the development of textbooks, the importance and ways of preparing teachers to participate in these activities and the problems they face.

Ukraine's desire to integrate into the world educational space requires an analysis of the experience of other countries. Under the influence of socio-political factors, in these countries, for decades, educational reforms has been implemented aimed at using innovative forms and methods in the system of teacher training and development adequate to the requirements of the time and conducive to continuous professional growth. Of particular interest is the experience of the United States, which has sufficient potential to implement the achievements of pedagogical science in practice.

The purpose of the article is to analyze the experience of American teachers in preparing teachers to participate in the development of textbooks, which can be taken into account in the process of reforming the educational system of Ukraine.

In accordance with the topic and purpose of the study, the author identified the following tasks:

1. To analyze scientific sources, identify the state of development of the research problem in pedagogical science.

2. To identify current trends in the system of professional development of teachers in the United States regarding their preparation for participation in the development of textbooks.

3. To describe the features of the organization of the professional development system in the United States, due to which it is adapted to prepare teachers to participate in the development of textbooks. 
Theoretical analysis of the problem field. Research on teacher professional development (TPD) in the area of establishing a link between the activities of teachers and textbooks focuses mainly on: the relationship between an educational program, a textbook as a means of its implementation and the activities of teachers in the classroom (Spring, 2002, pp. 226-255); giving the teacher the right for additional choice of teaching materials and selection of teaching methods (Tewel, 1995, p. 21); training teachers to carry out the learning process in accordance with clearly defined principles and programs, improving their pedagogical skills as a way to improve professional performance (Kennedy, 1991, pp. 11-12, 71-73).

Such areas of research reflect common views on the role of a teacher, which usually see a teacher as the performer of an educational program and the user of textbooks, who, however, can modify learning tasks, adapt materials according to class conditions and his/her own vision. However, in some works there is evidence of cases where the authors of textbooks are teachers (Boggs, 2019; Pecaski McLennan, 2013). In this regard, scholars are considering new roles of teachers that differ from those they have traditionally performed. In their view, efforts to reform education in the United States cannot succeed if they do not help teachers and administrators to accept these new roles (Darling-Hammond, 1997, p. 154). If teachers need to be prepared for much more challenging work, researchers say, they will need far more knowledge and radically different skills than most of them have now, and most schools of education are now evolving. But mostly it is about using teachers to test an experimental version of a new curriculum or a new textbook. Examples of this situation are found in some scientific works, in particular in the works of Pears (1988, p. 12-13), Venezky (1992, p. 436-443) and others.

Concerns that only a small number of teachers can influence the development of textbooks and even participate in their development are expressed by Rukhama Even and Shai Olsher (2014). The voice of most teachers, they say, remains unheard by textbook developers. Thus, the generally accepted relationship between program developers and teachers is mostly one-sided - from developers to teachers. Teachers' expectations about the desired textbooks, their appropriate adjustment based on the experience and knowledge of teachers often remain unknown to developers.

Analysis of scientific research shows that: 1 ) textbooks are the main means of implementing educational programs and the programs of academic disciplines, which significantly affect the learning process of students; 2 ) teachers through participation in the processes of adoption of educational programs influence the contents of textbooks; 3 ) however, they play a rather insignificant role in the development of textbooks; a small number of teachers are involved in this process.

In this context, the idea of involving teachers in professional training during the school year at each level, in the context of the subjects they teach, organized with the support of school management systems and education departments are considered important (Wei et al., 2009). Innovative are the proposals for training teachers to develop and implement new programs of academic disciplines by involving them in professional development programs (Ferrer Ariza \& Poole, 2018).

As for the problem of adaptation of TPD to teacher preparation for the development of textbooks in the United States, it is not sufficiently reflected in pedagogical theory, which complicates the study of the experience of American educators in these issues. This fact led to the choice of the topic of our study "Preparing Teachers in the Professional Development System for Participation in Textbook Development in the USA".

\section{METHODOLOGY}

This work is part of a larger comparative study of a group of employees of the department of scientific and methodological support of publishing educational literature of the Institute for 
Modernization of the Content of Education. In our study, we used a systemic approach that focuses on identifying integrative system-forming elements in TPD, clarifying their importance (level of training, content, forms and methods of teaching) for the development of teachers as subjects of textbook creation processes. From the standpoint of personality-oriented approach, the features of TPD in the USA, its adaptation to the specific needs and interests of teachers as future authors are considered. The introduction of a reflective-pragmatist approach involves identifying signs of enrichment of teachers' learning activities in the process of their professional development with creative-transforming, design, research aspects.

We used the following methods: study of scientific literature; analysis, generalization and systematization of information from scientific works, which allowed to clarify the features of the US TPD, through which the system is adapted to prepare teachers for the development of textbooks; theoretical generalization in order to formulate and substantiate the conclusions of this stage of the study. Criteria that guided the inclusion of scientific papers in our review are: the language of writing (English), the presence of citations, the elucidation of theoretical foundations, the availability of analysis of empirical data.

To search for literature, we used the holdings of Victor Kytastyi American Library of the National University "Kyiv Mohyla Academy," of Vasyl Sukhomlynskyi State Scientific and Pedagogical Library of Ukraine and Internet resources using the Google search engine.

The process of literature analysis took place at the following stages: 1) identification of the main authors and areas of their research, which is a significant contribution to the development of the problem of teacher training in the US professional development system; 2) determination of the competencies of the author of a textbook, at the development of which the process of teacher training in the system of professional development should be aimed; 3 ) identification of forms and methods of teaching that are empirically confirmed by researchers as useful for the development of a teacher as the author of a textbook.

We recognize that this methodology has some limitations. The study of the professional development of teachers as future authors should be aimed at studying more complex models. In our article, we do not seek to draw conclusions about the effectiveness of individual components of teacher training programs to create textbooks. On the contrary, we offer a description of the characteristics of some forms and methods that adapt the system of professional development to prepare teachers to participate in the creation of textbooks, positively influencing the results of their professional activities.

\section{RESEARCH FINDINGS}

An analysis of the scientific literature on the research problem shows that research focuses mainly on the educational role of teachers, the relationship between teacher activities and the use of textbooks as means of implementing approved educational programs. In their work, scholars note the limited involvement of teachers in the development of textbooks, which, in their opinion, was one of the factors behind the shortcomings of education reforms. Some works focus on teacher training and development, using effective practice models that have been successful in promoting teacher learning and supporting student achievement. But most of them do not focus specifically on the knowledge and skills needed by teachers as future authors.

This article discusses the learning opportunities available to US teachers and analyzes them in terms of focusing on helping teachers to become effective creators of textbooks and other learning materials.

Consideration of the research problem from this point of view allowed to envisage the preparation of teachers for the development of textbooks in the United States as a system. Based on the analysis of scientific works, a conclusion was made about a differentiated nature of the training: the initial stage of training occurs during the training of students-future teachers at higher 
education institutions; the stage of further training - in the process of professional activity of a teacher at an educational institution: the first level - for teachers who have recently started teaching; the second level - for experienced teachers.

The factors influencing the system of sustainable development of teachers, aimed at their broad participation in the creation of educational literature, are identified. In particular, the internal motivation of teachers (for example, to gain respect and recognition, to become a more effective teacher, etc.) as well as their external motivation (needs and requirements of the educational institution, compliance with which affects job retention, salary increase, career growth, etc.) are important.

An important role in this process is played by the state, which promotes TPD in this area. Various mechanisms are used, including support for special programs of non-profit educational organizations through the use of federal funds, the activities of the National Advisory Council, and so on. An example is the promotion of the US National Writing Project (NWP), which supports TPD programs designed to promote effective strategies. This finding is supported by the following data: NWR has almost 200 sites across the country, serving about 80,000 educators per year; federal funds cover $50 \%$ of the cost of teacher training programs; a survey of 110 teacher counselors and a survey of 1,848 NWP participants showed positive results: teachers refined or revised their writing philosophy, developed a writing process for students, and finally "linked their teaching of writing to their own experiences as writers, [positioning] themselves among students as writers among writers" (Athans, 2018, p. 45-46).

The analysis revealed current trends in the US TPD system regarding teacher training to develop textbooks: increasing variability in the forms of organization, content and process of teacher training, which provide flexibility in the professional development of teachers as textbook developers, directing this process to meet their individual learning needs; active introduction of innovative forms and methods of teaching in the system of teacher training for the activity of an author (including portfolio (electronic portfolio), supervision, telementoring, written reports and stories, cascading form, involvement in textbook editing, etc.), involving cooperation between teachers and support from the educational community; practical orientation of TPD, which supports the training of teachers in the context of a the activities of a particular school and emphasizes a teacher as an active and thinking person capable of creative activity including the creation of a textbook.

These trends characterize the system of teacher training to participate in the development of textbooks as one that develops in the direction of forming teachers as effective authors. The positive impact of these changes is confirmed by the following facts: the researchers' findings showed that students of teachers who had participated in any of the types of professional development were much more successful in passing testing than students whose teachers had not participated (with an average increase of $19-22 \%$ vs. $13 \%$ for the students in the control group) (Darling-Hammond et al., 2017, p. 11). However, perhaps partly due to the lack of scientific and pedagogical literature on the problem of research, we did not see this teacher training as a holistic system that is planned and constantly monitored by education authorities.

\section{DISCUSSION}

The teacher is the most important person in the implementation of an educational program, Merfat Ayesh Alsubaie (2016) is convinced. Teachers have the necessary theoretical knowledge, are familiar with the practice of teaching; as part of their duties, they are responsible for the implementation of the educational program and the programs of academic disciplines in the educational process. They have to create lesson plans and syllabi in accordance with the programs of academic disciplines, coordinating and directing the vector of development of educational materials toward the needs, interests and learning opportunities of the students. It happens that 
teachers themselves create them, take them from other sources, photocopy, mimeograph or reproduce them in some other way for use in the classroom (Pears, 1988, pp. 12-13).

Teaching is a science and an art that requires teachers to constantly study and change their approaches to teaching, says Robert J. Marzano. He argues that there is no single model or method of teaching that leads to effective learning for all children. Effective teachers find the right combination of strategies and teaching methods, taking into account the specifics of numerous variations in situations, content of educational material and types of students that occur in the continuum K - 12 (Marzano, 2007, p. 4).

Exploring the rights and opportunities of teachers to develop curricula, Arendt E. Carl argues that teachers should be seen as subjects of the educational process that influence changes in educational programs and curricula. They can contribute to successful and dynamic development of these documents if they are endowed with the appropriate skills and knowledge. Their positive attitude toward a program can be a motivating factor that adds value to the process of its development. Therefore, from the point of view of teachers, their ideas must be taken into account for the development of programs. Moreover, for successful and meaningful development of programs, teachers' own participation in their development is extremely important and necessary (Alsubaie, 2016).

Despite the fruitfulness of such teacher activities, some American researchers note, the approach to it is not clearly defined. Thus, the process of participation in the development can be difficult for teachers, burdensome with many problems (Alsubaie, 2016; Even \& Olsher, 2014, and others). Usually, schools, which are the most important clients of publishers and direct users of textbooks, do not have a direct influence on their development. Teachers are often involved in the activities of textbook acceptance committees, sometimes in local and state committees for the preparation of educational programs, and by selecting certain materials they can force publishers to reconsider some features of their products. However, teachers do not have any other organized communication channels to express the educational needs and interests of schools. As a group of professionals, they act at a great distance from the practical production of school books. Publishers turn out to be more influential than pedagogical teams (Pears, 1988; Venezky, 1992, pp. 442-445, 457).

Analysis of the literature on significant and consistent participation of teachers in the development of textbooks shows that such activities have not become common practice. The path of involving teachers in the development of textbooks is marked by many problems and conflict situations, but "problems are our friends," Carl Glickman, Stephen Gordon, Jovita Ross-Gordon (2013, p. 293) say. They need to be addressed so that the organization can find a reasonable solution (Alsubaie, 2016, p. 107).

An important factor contributing to the success in the development and implementation of a curriculum, the elimination of complications in this activity, in the opinion of Beth Handler (2010, p. 32), is the professional development of teachers. These considerations fully apply to the activities of teachers to create textbooks. Teachers should be provided with relevant knowledge and skills to help them become effective developers. Therefore, the formation of relevant competencies should include training and professional development programs for teachers. "Author" is considered synonymous with the term "creator," so he or she is one who creates. Although the roles of teacher and author complement each other, they do not coincide, and the corresponding competencies do not coincide either (Handler, 2010, pp. 34-35).

Teacher advanced training in the interpretation of E. Villegas-Reimers (2003) is an extended and continuous improvement that teachers must make as they move up the career ladder. This is not a one-time learning, but a combination of progressive, diverse and relevant learning, the results of which teachers implement in their practice (Ferrer Ariza \& Poole, 2018, p. 253). Some researchers recognize effective TPD as structured learning, which is a product of external and internal activities 
aimed at improving teachers' knowledge, changing their practical activities. Thus, TPD is a subset of experience that can lead to the formation of the necessary professional competencies (DarlingHammond, 2017, p. 2).

As we can see from the above definitions, the characteristic features of professional development are continuity, consistency, variety of forms and methods. It should be borne in mind that there is a difference between teacher training and teacher development. J.C. Richards and T.C.S. Farrell (2005, pp. 3-4) define teacher training as "an activity directly focused on the current responsibilities of the teacher and... aimed at short-term nearest goals" in order to prepare the teacher for taking new responsibilities or positions in their specific context. In contrast, teacher development tends to focus on "overall growth that does not focus on a specific work, serves a longterm goal and involves teacher reflection in his/her pedagogical practice. E. Ferrer Ariza and P.M. Poole (2018, p. 251) believe that both concepts are crucial for understanding the further growth of a teacher in the classroom and beyond. In the context of our study, it is important to find out how these processes occur if they are aimed at developing the competencies needed by a teacher as the author and teaching him/her to create textbooks.

Every author, according to I. Justesen (2019, points 1-10), needs the following skills: adaptive, research, organizational, editorial ones, the ability to create high quality content, communication, SEO, the ability to focus, the ability to meet deadlines. Among them, in our opinion, research skills (ability to find, view, analyze and interpret information) deserve special attention.

The formation of teachers' readiness for such activities begins during their studies at higher education institutions. At many American universities, it is popular to use a form such as a portfolio or e-portfolio. The purpose of a portfolio is to accumulate achievements, track professional progress and development. It is important that students from the first days of study start collecting teaching materials, which they can later use as an example of developing their own ones and as a certificate of formed competencies needed to obtain a license or certificate of teacher activity.

Although most students graduate with teaching skills, they do not have the relevant knowledge needed to develop textbooks. E. Ferrer Ariza and P.M. Poole (2018, point 'Teacher Development') justify the need for constant updating of professional knowledge and skills. This need is not a reflection of inadequate training, but only a reaction to the fact that not everything teachers need to know can be provided at any one previous level.

For teachers, professional development is a learning process, and because they are adults, the principles of adult learning apply. The importance of the ideas of adult learning theory for TPD is confirmed by Y.D. Trotter (2006, p. 11), L. Darling-Hammond, M.E. Hyler, and M. Gardner (2017, p. 7). They outline the main points to consider: adults should choose their learning path based on their own capabilities, professional interests, experience and needs; reflection and research should be central to their learning and development; adults come to learn with experiences that should be used as a learning resource. Studying the impact of teacher professional development on student learning, they used the results of a randomized experimental projection of Heller (2012). Professional development focused on the knowledge of teachers in the field of pedagogy using three different interventions (based on two experimental and one control group; all of them were successful in improving student achievement. However, the results of this study showed that students of teachers who had participated in any of the types of professional development, had much greater success in science tests than students whose teachers had not participated (with an average increase of $19-22 \%$ compared to $13 \%$ in the control group). The findings of this study are significant because the strongest effects are related to professional development focused on models of effective practice, including the implementation of curricula, presentation of material, analysis of student work and pedagogical activities of teachers with students in the classroom (Darling-Hammond et al., 2017, p. 11). 
Carrying out professional activities, teachers gain new knowledge and understanding of the needs of their students, educational program, teaching methods. They learn through various kinds of activities. The portfolio creation process is still useful. In teacher training, a portfolio is used as a collection of works and a description of teacher professional activities, professional growth and acquired skills. According to scientists K. Zeichner and S. Ray (2001, pp. 613-615, 620), the use of portfolios contributes to the deepening of knowledge of pedagogical theory, influencing the activities of teachers.

Another form of TPD that is considered important in the United States is supervision. Its function is to study the activities: learning activities, teaching methods, teacher activities and so on. Supervision is believed to have significant potential to improve teacher reflection, collaboration, and learning (Glickman et al., 2013, pp. 44-45, 233). Supervision is considered a separate area of educational practice, a scientific approach to learning, a flexible dialogue process between teacher and supervisor.

Starratt discovered supervision as a form of work that can be used to deliberately direct educators to participate in school renewal programs; in this context, it is considered an incentive for professional growth of educators. The main tasks of supervision are: providing mentoring for beginning teachers in order to support their entry into the profession; improving the professional competence of teachers aimed at improving the quality of the educational process (Starratt, 1997, para 10-11).

Another form reflected in pedagogical theory and practice is telementoring with the use of telecommunication technologies as a means of connecting individuals to meet their educational needs (Harris, 2010, point 'Background', para 1-2). The idea of telementoring as a means of supporting professional development of teachers is developed by Daisy Abbott (2003). Useful forms of mentoring are online discussions, e-mails about teaching practice, modeling of educational activities, etc.

The use of supervision and telementoring, of course, has positive features; in particular, it allows to directly monitor teaching activities, analyze information obtained, allows teachers to work with more experienced colleagues. Compared to other learning techniques, supervision and telementoring are considered imperfect, as they do not give a complete picture of lesson preparation and planning, teacher thinking processes. Probably in part because of this, the use of these forms as a means of shaping teachers as authors is not properly reflected in the scientific literature. However, as they provide practical suggestions that teachers can apply in their practice, they can be seen as a step in advancing teachers to the responsibilities of authors.

Speaking about the focus of the TPD system on preparing teachers for such activities, one should note the need to introduce forms of work aimed at developing competencies for written presentation of ideas. According to M. Eaton (2014, para 2-8), the following is important for an author: language proficiency in both form and function, which means correct use of words, sentences, paragraphs, sections; text structuring; character creation and plot development; speed and quality of writing.

We would like to note that in the United States, writing as an innovative form of preparation for authorial activity is of great importance. This is clearly demonstrated by the US National Writing Project (NWP), a nationwide nonprofit educational program that supports teacher development programs designed to promote effective writing strategies. It has nearly 200 sites nationwide that serve annually about 80,000 kindergarten educators who have college-level degree.

The main components of the NWP Summer Institute are reading and writing, reflection, inquiry, research, and collaboration. The overall structure of the NWP Summer Institute includes: keeping diaries, writing for different purposes, writing in different genres, questioning (investigating) lessons, best research practices, and working with other peer teachers to discuss classroom challenges and the best practices. Participants of the Summer Institute immerse 
themselves in reading and writing every day for five weeks and take on the role of students in which they go through the writing process, share their writing with their peers in groups, research survey and professional growth topics, present best writing learning practices to their peers and participate in writer workshops (Athans, 2018, p. 43).

The project provides a wide range of opportunities for teachers on the Internet, where they can interact, learn and work together in areas of interest. To provide these services, the NWP enters into agreements with higher education and non-profit educational institutions to implement small teacher training programs. Federal funds cover $50 \%$ of the cost of these programs. The NWP's activities are reviewed by the National Advisory Board, which provides it regular support and consultations. Collaboration with researchers, scholars and experts is important to help teachers, to test and improve approaches to their teaching. One of the most important results of the NWP programs, according to Kimberly Athans (2018, p. 70), is the fact that teachers leave the program confident in their writing skills and consider themselves writers. They return to their classes, looking for ways to incorporate the principles of authorship into their student training activities. This is clearly confirmed by a four-year study of the NWP legacy conducted by researchers Whitney and Friedrich. They interviewed 110 teacher counselors and 1,848 NWP participants to find out how teachers assess the impact of the NWP on their professional activities. Their research serves as a lens through which researchers can observe the legacy of the NWP, analyzing the rich testimony of teachers who participated in the project in 1974-1994. Based on this analysis, the areas of influence of the NWP heritage on these teachers in their classroom work were identified. Among them, according to researchers, the result of the teachers' participation in NWP was the following: the teachers clarified or revised their writing philosophy; they developed a writing process for students and, finally, linked students' writing learning with their own experience as writers, positioning themselves in the classroom as writers among writers (Athans, 2018, p. 45-46).

Writing for Learning is a slogan underlying the NWP philosophy; it also applies to other learning strategies that use writing as a means of preparing teachers to create textbooks. One of the forms of work that allows teachers to reflect their thoughts on paper is a written report, which provides for the accumulation of materials related to the experience gained by the teachers, its analysis and generalization. Ershler (2001, p. 163) identifies three stages of work on a written report: writing a report; acquaintance of colleagues with the report; discussion of the content of the report and its consideration by members of the professional community. Researchers also note a positive impact on the professional development of teachers of such a form of work as teachers' stories. Its essence is that a teacher writes stories about cases in his/her professional activities with their further dissemination among colleagues and joint discussion (Golombek \& Johnson, 2017).

Taking into account the views of his/her colleagues, an author teacher has the opportunity to adjust his/her own professional activities and behavior (Martin et al., 2018). In the process of forming a teacher as a future author, the forms of written report and teachers' stories are important: being implemented through writing, they form skills of reflective practice, give the teacher valuable experience in creating written works in the field of pedagogy.

One of the innovative forms is the cascading model, according to which selected teachers undergo "instructor training" and return to their schools, where they conduct training with their colleagues (Kinsey, 2021). Researchers note that the cascading form has advantages over traditional ones: it creates conditions for simultaneous coverage of many teachers with standardized professional development; the level of pedagogical competence of teachers is the basis of their professional development, which increases its effectiveness; cascading training ensures the continuity of teacher training for professional development.

\section{CONCLUSIONS}


The analysis showed that the system of teacher training to participate in the development of textbooks is characterized by the presence of alternative models, a large number of programs, a variety of content and organizational forms of learning. However, the presence of problems in the process of involving teachers in the creation of textbooks indicates the need for further development of this system by improving management mechanisms. At the same time, it should be borne in mind that well-designed models and programs may not give the desired results if there are numerous obstacles to their implementation, in particular, such as: lack of proper legislative support for teachers as authors and their appropriate training; lack of planned and systematic training of teachers to participate in the creation of textbooks in the system of professional development; insufficient resources, including financial, insufficient material and technical, educational and methodological resources; vaguely defined requirements for the content of programs for teachers to prepare them for participation in the creation of textbooks in the system of professional development.

These barriers should be anticipated and prevented at the design and implementation stages. Effective implementation of programs training teachers so that they become authors requires a response to their professional interests, needs and the context in which the learning process takes place. A well-designed and implemented teacher training program should be considered an important component of a comprehensive professional development system that helps teachers develop the competencies needed to create textbooks.

Theoretical analysis of the US experience in the professional development of teachers as future authors of textbooks allows to take it into account in the process of modernization of the education system of Ukraine. This analysis reveals opportunities for creating a system of teacher training to prepare teachers for real participation in the creation of textbooks in the Ukrainian system of professional teacher training.

Authors' Contributions: Elbrekht, O. M.: conception and design, acquisition of data, analysis and interpretation of data; analysis and interpretation of data, critical review of important intellectual content. Bakhov, I.: conception and design, acquisition of data, analysis and interpretation of data; analysis and interpretation of data, critical review of important intellectual content. Vukolova, K.: conception and design, acquisition of data, analysis and interpretation of data; analysis and interpretation of data, critical review of important intellectual content. Kostenko, L. D.: conception and design, acquisition of data, analysis and interpretation of data; analysis and interpretation of data, critical review of important intellectual content. All authors have read and approved the final version of the manuscript.

Ethics Approval: Not applicable.

Acknowledgments: Not applicable.

\section{REFERENCES}

Alsubaie, M. A. (2016). Curriculum development: Teacher involvement in curriculum development. Journal of Education and Practice, 7(9), 106-107. Available: https://files.eric.ed.gov/fulltext/EJ1095725.pdf

Athans, K. (2018). National writing project fellows' perceptions of themselves as writers and as teachers of writing. Doctoral dissertation. Sam Houston State University, Huntsville, 246 p.

Boggs, B. (2019, April 2). Why don't more writers become public school teachers? Literary Hub. Available: https://lithub.com/why-dont-more-writers-become-public-school-teachers/

Daisy, A. L. (2003). Novice teachers' experiences with telementoring as learner-centered professional development. Doctoral dissertation. University of Texas at Austin, Austin.

Darling-Hammond, L. (1997). The right to learn: A blueprint for creating schools that work. San Francisco: Jossey Bass.

Darling-Hammond, L., Hyler, M. E., \& Gardner, M. (2017). Effective teacher professional development. Palo Alto: Learning Policy Institute, p. 64.

Eaton, M. (2014, April 25). The 7 core competencies vital to writing success. Available:

https://www.helpingwritersbecomeauthors.com/writing-success/ 
Ershler, A. R. (2001). The narrative as an experience text: Writing themselves back. In: Lieberman, A., Miller, L. (Eds.). Teachers caught in action: professional development that matter. New York: Teacher College Press, pp. $159-173$.

Even, R., \& Olsher, S. (2014). Teachers as participants in textbook development: The integrated mathematics wikibook project. In: Li, Y., \& Lappan, G. (Eds.). Mathematics curriculum in school education. New York: Springer, pp. 333350 .

Ferrer Ariza, E., \& Poole, P. M. (2018). Creating a teacher development program linked to curriculum renewal. Profile: Issues in Teachers' Professional Development, 20(2), 249-266. https://doi.org/10.15446/profile.v20n2.67937

Glickman, C. D., Gordon, S. P., \& Ross-Gordon, J. M. (2013). Basic guide to supervision and instructional leadership (3rd ed.). Boston: Pearson, 384 p.

Golombek, P. R., \& Johnson, K. E. (2017). Re-conceptualizing teachers' narrative inquiry as professional development. PROFILE Issues in Teachers' Professional Development, 19(2), 15-28. http://dx.doi.org/10.15446/profile.v19n2.65692

Handler, B. (2010). Teacher as curriculum leader: A consideration of the appropriateness of that role assignment to classroom-based practitioners. International Journal of Teacher Leadership, 3, 32-42.

Harris, J. (2010). Facilitated telementoring for K-12 students and teachers. In: Berg, G. A. (Ed.). Cases on online tutoring, mentoring and educational services: Practices and applications. Hershey: IGI Global, pp. 1-11.

Heller, R., Heller, Y., Gorfine, M. (2012). A consistent multivariate test of association based on ranks of distances. Biometrika, 100(2), 503-510. https://doi.org/10.1093/biomet/ass070

Justesen, I. (2019, January 9). 10 Skills every great content writer needs. Available: https://www.constantcontent.com/content-writing-service/2019/01/skills-content-writer/

Kennedy, M. M. (1991). Teaching academic subjects to diverse learners. New York: Teachers College Press, 298 p.

Kinsey, M. (2021). Adapting the cascade approach to teacher professional development. Cambridge Education. Available: https://www.camb-ed.com/article/481/adapting-the-cascade-approach-to-teacher-professionaldevelopment

Martin, A., Tarnanen, M., \& Tynjälä, P. (2018). Exploring teachers' stories of writing: a narrative perspective. Teachers and Teaching, 24(6), 690-705. http://dx.doi.org/10.1080/13540602.2018.1462790

Marzano, R. J. (2007). The art and science of teaching: a comprehensive framework for effective instruction. Alexandria: Association for Supervision and Curriculum Development, $233 \mathrm{p}$.

Pears, D. (1988). A guide to planning and administrating government school projects. With special emphasis on costreduction factors. Paris: UNESCO, $95 \mathrm{p}$.

Pecaski McLennan, D. M. (2013). Educators as authors: Teaching beyond the classroom. Early Childhood Education Journal, 41, 1-4. https://doi.org/10.1007/s10643-012-0558-1

Richards, J. C., \& Farrell, T. S. C. (2005). Professional development for language teachers: strategies for teacher learning. Cambridge: Cambridge University Press.

Spring, J. (2002). American education (10th ed.). Boston: McGraw-Hill Higher Education, 305 p.

Starratt, R. J. (1997). Supervision of instruction. The history of supervision, roles and responsibilities of supervisors, issues trends and controversies. Education Encyclopedia. StateUniversity.com. Available:

https://education.stateuniversity.com/pages/2472/Supervision-Instruction.html

Tewel, K. J. (1995). New schools for a new century: a leader`s guide to high school reform. Delray Beach: St. Lucie Press, $231 \mathrm{p}$.

Trotter, Y. D. (2006). Adult learning theories: Impacting professional development programs. Delta Kappa Gamma Bulletin, 72(2), 8-13.

Venezky, R. L. (1992). Textbooks in school and society. In: Jackson, P. (Ed.). Handbook of research on curriculum: A project of the American Educational Research Association. New York: Macmillan Pub. Co, pp. 436-443.

Villegas-Reimers, E. (2003). Teacher professional development: An international review of the literature. Paris: UNESCO International Institute for Educational Planning.

Wei, R. C., Darling-Hammond, L., Andree, A., Richardson, N., \& Orphanos, S. (2009). Professional learning in the learning profession: A status report on teacher development in the United States and abroad. Dallas: National Staff Development Council. 
Zeichner, K., \& Wray, S. (2001). The teaching portfolio in US teacher education programs: What we know and what we need to know. Teaching and Teacher Education, 17(5), 613-621. http://dx.doi.org/10.1016/S0742-051X(01)00017-8

Received: 27 August 2021 | Accepted: 12 November 2021 | Published: 21 December 2021

This is an Open Access article distributed under the terms of the Creative Commons Attribution License, which permits unrestricted use, distribution, and reproduction in any medium, provided the original work is properly cited. 